\title{
Pengaruh Model Pembelajaran Kooperatif dengan Snowball Throwing Terhadap Hasil Belajar IPA Pada Siswa Kelas IV SDN Bondrang Kecamatan Sawoo Kabupaten Ponorogo
}

\author{
Naniek Kusumawati \\ Dosen Prodi PGSD Universitas PGRI Madiun \\ naniekkusumawati@gmail.com
}

\begin{abstract}
Abstrak
Pada pembelajaran IPA di Sekolah Dasar membutuhkan suatu inovasi baru yang mampu untuk mengaktifkan dan membuat proses pembelajaran menjadi lebih menyenangkan agar para siswa mampu untuk memahami materi yang dipelajari. Hal ini menuntut guru untuk dapat menjadi lebih kreatif dan inovatif dalam memilih model pembelajaran yang akan digunakan. Salah satu contoh model pembelajaran yang dapat digunakan adalah model pembelajaran kooperatif Snowball Throwing. Dalam pembelajaran Snowball Throwing siswa akan belajar secara berkelompok dan bekerjasama dengan teman sekelompoknya dalam memecahkan masalah. Sehingga siswa akan lebih mudah dalam memahami materi dan juga dalam mengemukakan ide yang dapat memaksimalkan hasil belajar. Penelitian ini bertujuan untuk mengetahui ada atau tidaknya pengaruh model pembelajaran kooperatif dengan Snowball Throwing terhadap hasil belajar IPA pada siswa kelas IV SDN Bondrang Kecamatan Sawoo Kabupaten Ponorogo tahun pelajaran 2016/2017. Subyek dalam penelitian ini adalah siswa kelas IV SDN 1 Bondrang dan siswa kelas IV SDN 2 Bondrang. Dalam penelitian ini menggunakan pendekatan kuantitatif dengan metode penelitian eksperimen. Pengambilan sampel penelitian dilakukan dengan sampling jenuh. Sedangkan dalam rangka pengumpulan data peneliti menggunakan metode tes, dan dokumentasi. Teknik analisis data yang digunakan dalam penelitian ini adalah uji prasyarat dan uji hipotesis. Hasil penelitian menunjukkan bahwa penerapan model pembelajaran Snowball Throwing dapat mempengaruhi hasil belajar IPA siswa kelas IV SDN Bondrang Kabupaten Ponorogo, dimana diperoleh hasil nilai rata-rata pada kelas eksperimen adalah 83,23 dan pada kelas kontrol adalah 71,47. Simpulan pada penelitian ini adalah ada pengaruh dari penerapan model pembelajaran kooperatif dengan Snowball Throwing terhadap hasil belajar IPA pada siswa kelas IV SDN Bondrang Kecamatan Sawoo Kabupaten Ponorogo tahun pelajaran 2016/2017.
\end{abstract}

Kata Kunci:Pengaruh Model Pembelajaran, Pembelajaran Kooperatif Snowball Throwing, Hasil Belajar IPA 


\begin{abstract}
In learning science in elementary school requires a new innovation that is able to activate and make the learning process more enjoyable so that students are able to understand the material being studied. This requires teachers to be more creative and innovative in selecting a learning model that will be used. One example of learning model that can be used is a cooperative learning model Snowball Throwing. Throwing Snowball In lessons students will learn in groups and in collaboration with the group of their friends in solving problems. So that students can easily understand the material and also in expressing ideas that can maximize learning outcomes. This study aims to determine whether or not the influence of cooperative learning model with Snowball Throwing on learning outcomes of science in grade IV SDN Bondrang Sawoo District of Ponorogo in the academic year 2016/2017. Subjects in this study were students of class IV SDN 1 Bondrang and fourth grade students of SDN 2 Bondrang.In this study, using a quantitative approach to experimental research methods. Sampling was done by sampling research saturated. While the researchers to collect data using the test method, and documentation. Data analysis techniques used in this research is the prerequisite test and test hypotheses. The results showed that the application of learning models Snowball Throwing can affect learning outcomes IPA grade IV SDN Bondrang Ponorogo, where the result the average value of the experimental class was 83.23 and in control group was 71.47. The conclusions of this research is no effect of the application of cooperative learning model with Snowball Throwing on learning outcomes of science in grade IV SDN Bondrang Sawoo District of Ponorogo in the academic year 2016/2017.
\end{abstract}

Keywords : Effects of Learning Model, Snowball Throwing Cooperative Learning, Learning Outcomes IPA

\section{A. PENDAHULUAN}

Pendidikan adalah usaha sadar dan terencana untuk mewujudkan suasana belajar dan proses pembelajaran agar peserta didik secara aktif mengembangkan potensi dirinya untuk memiliki spiritual keagamaan, pengendalian diri, kepribadian, kecerdasan, akhlak mulia, serta keterampilan yang diperlukan dirinya dan masyarakat. Pendidikan merupakan suatu kegiatan yang dinamis dan penuh tantangan, pendidikan juga selalu berubahubah seiring dengan perubahan jaman. Sehingga senantiasa perlu adanya upaya untuk perbaikan dan peningkatan mutu pendidikan yang sejalan dengan semakin tingginya kebutuhan dan tuntunan kehidupan masyarakat. Berbagai cara dilakukan pemerintah untuk meningkatkan kualitas pendidikan dengan adanya berbagai kebijakan dan juga inovasi.

Pembaharuan kurikulum sering dilakukan untuk meningkatkan atau memperbaiki kualitas pendidikan. Pada tahun 2013 pemerintah melakukan pembaharuan kurikulum pendidikan untuk menyesuaikan dan memperbaiki kurikulum sebelumnya. Pemerintah telah memutuskan digunakannya kurikulum baru yang disebut dengan Kurikulum 2013. 
Pembelajaran Kurikulum 2013 difokuskan pada penguatan pelaksanaan kurikulum berbasis kompetensi dalam pembelajaran; penguatan pengetahuan, keterampilan, dan sikap secara holistik dalam pembelajaran; penguatan pembelajaran siswa aktif; dari siswa diberi tahu menjadi siswa tahu dari berbagai sumber belajar dan penguatan penilaian proses dan hasil 1. Kualitas pendidikan sekarang ini semakin menurun, dikarenakan rendahnya kompetensi guru dalam pembelajaran di kelas dan kualitas seorang guru dapat mempengaruhi hasil belajar siswa. Hasil belajar siswa sering mengalami penurunan dengan bertambahnya materi pelajaran yang diberikan oleh guru karena siswa kurang memperhatikan guru ketika menyampaikan materi pelajaran.

Dengan demikian, perlu adanya inovasi-inovasi baru dalam pembelajaran untuk meningkatkan minat siswa khususnya pada mata pelajaran IPA sehingga dengan adanya inovasi pembelajaran tersebut akan dapat meningkatkan hasil belajar siswa. Banyak cara yang dapat ditempuh agar siswa menjadi lebih aktif dalam proses pembelajaran. Salah satu contohnya dengan merubah pola pembelajaran yang dilakukan. Guru bukan sebagai pusat pembelajaran, melainkan sebagai pembimbing, fasilitator, dan juga motivator. Dimana selama proses pembelajaran siswa dituntut untuk lebih aktif. Dengan adanya keaktifan siswa dalam proses pembelajaran akan tercipta situasi belajar yang aktif. Salah satunya adalah

\footnotetext{
${ }^{1}$ L Malawi and K Anik, Pembaharuan Pembelajaran Di Sekolah Dasar (Magetan: CV. AE Media Grafika, 2015), 190-91.
}

dalam pembelajaran IPA. Belajar IPA sering kali membuat siswa merasa bosan. Banyak siswa yang merasa bosan, sama sekali tidak tertarik dan bahkan tidak menyukai pelajaran IPA.

Oleh karena itu guru perlu melakukan inovasi baru dalam pembelajaran. Salah satunya guru dapat mengembangkan penggunaan model pembelajaran yang mampu menunjang atau mampu meningkatkan keaktifan siswa dan juga hasil belajar siswa.

Salah satu model pembelajaran yang dapat digunakan yaitu adalah model pembelajaran Snowball Throwing. Model pembelajaran Snowball Throwing merupakan model pembelajaran kooperatif. Dimana dalam model pembelajaran ini siswa dibentuk menjadi beberapa kelompok yang kemudian siswa membuat suatu pertanyaan sesuai dengan materi yang telah diajarkan sebelumnya dalam sebuah kertas yang kemudian kertas tersebut dibentuk menyerupai bola yang kemudian dilempar ke siswa lain dan siswa yang mendapat bola tersebut menjawab pertanyaan yang terdapat di dalamnya. Keuntungan dari model pembelajaran ini adalah dapat membuat siswa menjadi lebih aktif dalam pembelajaran, siswa siap dengan berbagai kemungkinan karena siswa tidak tahu soal yang dibuat temannya seperti apa, pembelajaran menjadi lebih efektif, dan aspek kognitif, afektif, dan psikomotor dapat tercapai. Meskipun begitu model pembelajaran Snowball Throwing juga memiliki kekurangan seperti halnya memerlukan yang panjang dalam proses pembelajaran. 
Penelitian serupa telah dilakukan oleh Md. Puspa Dewi, I Kt. Adnyana Putra, dan I Gst. A. Oka Negara. Penelitian itu berupa tulisan di jurnal dengan judul "Pengaruh Model Pembelajaran Snowball Throwing Terhadap Hasil Belajar IPA Siswa Kelas V SD Di Gugus Sri Kandi Kecamatan Denpasar Timur". Penelitian tersebut dilaksanakan pada tahun ajaran 2012/2013. Dari penelitian tersebut diperoleh bahwa dengan menggunakan model pembelajaran Snowball Throwing sangat membantu siswa kelas V SD di gugus Sri Kandi Kecamatan Denpasar Timur dalam meningkatkan hasil belajar.

Berdasarkan uraian latar belakang di atas, rumusan judul penelitian adalah "Pengaruh Model Pembelajaran Kooperatif dengan Snowball Throwing Terhadap Hasil Belajar IPA Pada Siswa Kelas IV SDN Bondrang Kecamatan Sawoo Kabupaten Ponorogo Tahun Pelajaran 2016/2017".

\section{B. KAJIAN PUSTAKA}

1. Belajar dan Pembelajaran

a. Pengertian Belajar

Secara psikologis belajar merupakan suatu proses perubahan yaitu perubahan tingkah laku sebagai hasil dari interaksi dengan lingkungannya dalam memenuhi kehidupnya ${ }^{2}$.

Menurut Suyono dan Hariyanto ${ }^{3}$ belajar adalah suatu aktivitas atau suatu proses untuk memperoleh pengetahuan, meningkatkan keterampi-

\footnotetext{
${ }^{2}$ Slameto, Belajar Dan Faktor-Faktor Yang Mempengaruhi (Jakarta: Rineka Cipta, 2010), 2.

${ }^{3}$ Suyono and Hariyanto, Belajar Dan Pembelajaran Teori Dan Konsep Dasar (Bandung: PT. Remaja Rosdakarya, 2012), 9.
}

lan, memperbaiki perilaku, sikap, dan mengokohkan kepribadian.

b. Ciri-Ciri Belajar

Baharuddin dan Esa ${ }^{4}$ mengungkapkan beberapa ciri-ciri belajar, yaitu :

a) Belajar ditandai dengan adanya perubahan tingkah laku (change behavior).

b) Perubahan perilaku relative permanent.

c) Perubahan tingkah laku tidak harus segera dapat diamati pada saat proses belajar sedang berlangsung, perubahan perilaku tersebut bersifat potensial.

d) Perubahan tingkah laku merupakan hasil latihan atau pengalaman.

e) Pengalaman atau latihan itu dapat memberi penguatan.

c. Prinsip-Prinsip Belajar

Menurut Soekamto dan Winataputra $^{5}$ dalam tugas melaksanakan proses belajar mengajar, seorang guru perlu memperhatikan beberapa prinsip belajar sebagai berikut :

a) Apapun yang dipelajari siswa, dialah yang harus belajar, bukan orang lain. Untuk itu, siswalah yang harus bertindak aktif.

b) Setiap siswa belajar sesuai dengan tingkat kemampuannya.

c) Siswa akan dapat belajar dengan baik bila mendapat penguatan langsung pada setiap langkah yang dilakukan selama proses belajar.

\footnotetext{
${ }^{4}$ Baharuddin and N Esa, Teori Belajar Dan

Pembelajaran (Yogyakarta: Ar-Ruzz Media, 2007), 15.

${ }^{5}$ Ibid., 16.
} 
d) Penguasaan yang sempurna dari setiap langkah yang dilakukan siswa akan membuat proses belajar lebih berarti.

e) Motivasi belajar siswa akan lebih meningkat apabila ia diberi tanggung jawab dan kepercayaan penuh atas belajarnya.

d. Pengertian Pembelajaran

Secara harfiah pembelajaran berarti proses, cara, perbuatan mempelajari, dan perbuatan menjadikan orang atau makhluk hidup belajar.

Menurut Isjoni ${ }^{6}$ pembelajaran adalah sesuatu yang dilakukan oleh siswa bukan dibuat untuk siswa. Tujuan pembelajaran adalah terwujudnya efisiensi dan efektivitas kegiatan belajar yang dilakukan peserta didik.

\section{Hasil Belajar}

Hasil belajar merupakan perubahan-perubahan yang terjadi pada diri siswa, baik yang menyangkut aspek kognitif, afektif, dan psikomotor sebagai hasil dari kegiatan belajar?

Faktor-faktor yang mempengaruhi hasil belajar menurut Munadi ${ }^{8}$ meliputi faktor internal dan eksternal, yaitu :

a. Faktor Internal

a) Faktor Fisiologis

b) Faktor Psikologis

b. Faktor Eksternal

a) Faktor Lingkungan

\footnotetext{
${ }^{6}$ Isjoni, Pembelajaran Kooperatif Meningkatkan Kecerdasan Komunikasi Anatar Peserta Didik (Yogyakarta: Pustaka Pelajar, 2011), 14.

${ }^{7}$ A Susanto, Teori Belajar Dan Pembelajaran Di Sekolah Dasar (Jakarta: Kencana Prenadamedia Group, 2013), 5.

${ }^{8}$ Rusman, Belajar Dan Pembelajaran Berbasis Komputer (Bandung: Alfabeta, 2013), 124.
}

b) Faktor Instrumental

\section{Hakikat IPA}

Menurut Samatowa ${ }^{9} \quad$ Ilmu pengetahuan alam merupakan terjemahan kata-kata dalam bahasa Inggris yaitu natural science, artinya ilmu pengetahuan alam (IPA).

IPA merupakan rumpun ilmu, memiliki karakteristik khusus yaitu mempelajari fenomena alam yang faktual (factual), baik berupa kenyataan (reality) atau kejadian (events) dan hubungan sebab-akibatnya ${ }^{10}$.

4. Model Pembelajaran

a. Model Pembelajaran Kooperatif

Pembelajaran kooperatif berasal dari kata cooperative yang artinya mengerjakan sesuatu secara bersama-sama dengan saling membantu satu sama lainnya sebagai satu kelompok atau satu tim ${ }^{11}$.

Salah satu asumsi yang mendasari pengembangan pem-belajaran kooperatif (cooperative learning) adalah bahwa sinergi yang muncul melalui kerja sama akan meningkatkan motivasi yang jauh lebih besar daripada melalui ling-kungan kompetitif individual ${ }^{12}$.

b. Pengertian Model Pembelajaran

\footnotetext{
${ }^{9}$ U Samatowa, Pembelajaran IPA Di Sekolah Dasar (Jakarta Barat: Permata Puri Media, 2010), 3.

${ }^{10}$ A.W Wisudawati and S Eka, Metodologi Pembelajaran IPA (Jakarta: Bumi Aksara, 2014), 22.

${ }^{11}$ Isjoni and Mohd. Arif, Model-Model Pembelajaran Mutakhir (Yogyakarta: Pustaka Pelajar, 2008), 150.

${ }^{12}$ M Huda, Model-Model Pengajaran Dan Pembelajaran (Yogyakarta: Pustaka Pelajar, 2013), 111.
} 
Model pembelajaran dapat diartikan sebagai pola yang digunakan untuk penyusunan kurikulum, pengaturan materi dan memberi petunjuk kepada guru di kelas ${ }^{13}$.

Menurut Suryaman ${ }^{14}$ merumuskan model pembelajaran adalah kerangka konseptual yang melukiskan prosedur yang sistematis dalam mengorganisasikan pengalaman belajar untuk mencapai tujuan belajar tertentu dan berfungsi sebagai pedoman bagi para perancang pembelajaran dan para pengajar dalam merencanakan dan melak-sanakan aktivitas pembelajaran.

c. Model Pembelajaran Snowball Throwing

a. Pengertian Model Pembelajaran Snowball Throwing

Snowball secara etimologi berarti bola salju, sedangkan throwing artinya melempar. Snowball throwing secara keseluruhan dapat diartikan melempar bola salju ${ }^{15}$.

Snowball Throwing (ST) atau yang juga sering dikenal dengan Snowball Fight merupakan pembelajaran yang diadopsi pertama kali dari game fisik dimana segumpalan salju dilempar de-

\footnotetext{
${ }^{13}$ N Suryani and A Leo, Strategi Belajar Mengajar (Yogyakarta: Penerbit Ombak, 2012), 8.

${ }^{14}$ T Suharto, Pengantar Teori Belajar Dan Pembelajaran Bahasa Dan Sastra Berbasis Pengalaman (Salatiga: Widya Sari Press Salatiga, 2015), 83.

${ }^{15}$ J Hamdayama, Model Dan Metode Pembelajaran Kreatif Dan Berkarakter (Bogor: Ghalia Indonesia, 2014), 158.
}

ngan maksud memukul orang lain ${ }^{16}$.

b. Kelebihan dan Kelemahan Model Pembelajaran Snowball Throwing a) Kelebihan

Menurut Hamdayama ${ }^{17}$ kelebihan dari model pembelajaran Snowball Throwing sebagai berikut :

1. Suasana pembelajaran menjadi menyenangkan karena siswa seperti bermain dengan melempar bola kertas kepada siswa lain.

2. Siswa mendapat kesempatan untuk mengembangkan kemampuan berfikir karena diberi kesempatan untuk membuat soal dan diberikan pada siswa lain.

3. Membuat siswa siap dengan berbagai kemungkinan karena siswa tidak tahu soal yang dibuat temannya seperti apa.

4. Siswa terlibat aktif dalam pembelajaran.

5. Pendidik tidak terlalu repot membuat media karena siswa terjun langsung dalam praktik.

6. Pembelajaran menjadi lebih efektif.

7. Aspek kognitif, afektif, dan psikomotor dapat tercapai.

b) Kelemahan

Menurut Hamdayama ${ }^{18}$ kelemahan dari model pembelajaran

\footnotetext{
${ }^{16}$ Huda, Model-Model Pengajaran Dan

Pembelajaran, 226.

${ }^{17}$ Hamdayama, Model Dan Metode Pembelajaran Kreatif Dan Berkarakter, 161.

${ }^{18}$ Ibid.
} 
Snowball Throwing sebagai berikut :

1. Sangat bergantung pada kemampuan siswa dalam memahami materi sehingga apa yang dikuasai siswa hanya sedikit.

2. Ketua kelompok yang tidak mampu menjelaskan dengan baik tentu menjadi penghambat bagi anggota lain untuk memahami materi sehingga diperlukan waktu yang tidak sedikit untuk siswa mendiskusikan materi pelajaran.

3. Tidak ada kuis individu maupun penghargaan kelompok sehingga siswa saat berkelompok kurang termotivasi untuk bekerja sama tapi tidak menutup kemungkinan bagi guru untuk menambahkan pemberian kuis individu dan penghargaan kelompok.

4. Memerlukan waktu yang panjang.

5. Murid yang nakal cenderung untuk berbuat onar.

6. Kelas sering kali gaduh karena kelompok dibuat oleh murid.

c. Langkah-Langkah Model Pembelajaran Snowball Throwing

Menurut Aqib ${ }^{19}$ langkah-langkah model pembelajaran Snowball Throwing adalah sebagai berikut :

1. Guru menyampaikan materi yang akan disajikan.

\footnotetext{
${ }^{19}$ Z Aqib, Model-Model, Media, Dan Strategi Pembelajaran Kontekstual (Inovatif) (Bandung: Yrama Widya, 2013), 27-28.
}

2. Guru membentuk kelompokkelompok dan memanggil masingmasing ketua kelompok untuk memberikan penjelasan tentang materi.

3. Masing-masing ketua kelompok kembali ke kelompoknya masingmaisng, kemudian menjelaskan materi yang disampaikan oleh guru kepada temannya.

4. Kemudian masing-masing siswa diberikan satu lembar kertas kerja untuk menuliskan satu pertanyaan apa saja yang menyangkut materi yang sudah dijelaskan oleh ketua kelompok.

5. Kemudian kertas tersebut dibuat seperti bola dan dilempar dari satu siswa ke siswa yang lain selama kurang lebih 15 menit.

6. Setelah siswa dapat satu bola atau satu pertanyaan diberikan kesempatan kepada siswa untuk menjawab pertanyaan yang tertulis dalam kertas berbentuk bola tersebut secara bergantian.

7. Evaluasi.

8. Penutup.

\section{METODE PENELITIAN}

Penelitian ini dilaksanakan di SDN Bondrang Kecamatan Sawoo Kabupaten Ponorogo. Waktu penelitian dilaksanakan pada bulan Maret 2017 - Mei 2017.

Penelitian ini menggunakan pendekatan kuantitatif dengan metode eksperimen. Desain penelitian yang digunakan dalam penelitian ini adalah Post Test Only Group Design. Dalam desain ini terdapat dua kelompok yang dipilih secara random, 
kelompok pertama diberi perlakuan (X) dan kelompok kedua tidak, pengaruh adanya perlakuan (treatment) adalah $\mathrm{O}_{1}$ $\operatorname{danO}_{2} 20$.

Variabel bebas dalam penelitian ini adalah model pembelajaran kooperatif dengan Snowball Throwing. Sedangkan variabel terikat dalam penelitian ini adalah hasil belajar IPA.

Populasi dari penelitian ini adalah seluruh siswa kelas IV SDN Bondrang Kecamatan Sawoo Kabupaten Ponorogo. Teknik pengambilan sampel yang digunakan adalah Sampling Jenuh, Hal ini dilakukan karena jumlah populasinya relatif kecil, kurang dari 30 orang 21 .

Teknik pengumpulan data yang digunakan dalam penelitian ini adalah tes dan non tes. Tes meliputi soal-soal tes yang terdiri 15 soal pilihan ganda dan 5 soal uraian. Sedangkan non tes terdiri atas silabus permendikbud, RPP dari guru, nilai siswa, dan dokumentasi. Instrumen yang digunakan adalah Rencana Pelaksanaan Pembelajaran (RPP) dan Tes. Adapun prasyarat yang harus dipenuhi dalam instrumen penelitian terdiri dari uji validitas, uji reliabilitas, uji daya beda, dan uji taraf kesukaran.

Teknik analisis data merupakan kegiatan setelah data dari seluruh sumber data telah terkumpul. Sebelum melakukan analisis data, terdapat uji prasyarat data yakni uji normalitas, uji homogenitas, dan uji hipotesis.

\footnotetext{
${ }^{20}$ Sugiyono, Metode Penelitian Kuantitatif, Kualitatif, Dan R\&D (Bandung: Alfabeta, 2013), 76.

${ }^{21}$ Ibid., 126.
}

\section{HASIL PENELITIAN}

Hasil dari penelitian dengan menggunakan model Snowball Throwing dan Konvensional dapat dilihat dari tabel berikut :

Tabel 1 Rangkuman Nilai Kelas Eksperimen dan Kontrol.

\begin{tabular}{|l|l|l|}
\hline & $\begin{array}{l}\text { Kelas } \\
\text { Eksperimen }\end{array}$ & $\begin{array}{l}\text { Kelas } \\
\text { Kontrol }\end{array}$ \\
\hline Nilai Tertinggi & 90 & 80 \\
\hline Nilai Terendah & 75 & 65 \\
\hline Mean & 83,23 & 71,47 \\
\hline Modus & 85 & 75 \\
\hline Median & 85 & 70 \\
\hline Standart Deviasi & 5,28 & 5,23 \\
\hline
\end{tabular}

Dari tabel di atas dapat dilihat bahwa kelas eksperimen yang menggunakan model Snowball Throwing memiliki nilai lebih unggul dibandingkan dengan kelas kontrol yang tidak menggunakan model Snowball Throwing.

Uji prasyarat meliputi uji normalitas dan uji homogentias. Data yang digunakan dalam uji prasyarat ini diperoleh dari hasil tes nilai siswa kelas IV SDN 1 Bondrang (kelas eksperimen) dan kelas IV SDN 2 Bondrang (kelas kontrol) yang berjumlah 20 soal. Berikut adalah rangkuman hasil uji prasyarat uji normalitas dan uji homogenitas.

a. Uji Normalitas

Tabel 2 Rangkuman Uji Normalitas

\begin{tabular}{|c|c|c|c|}
\hline Kelas & Lhitung & Ltabel & Kesimpulan \\
\hline Eksperime & 0,1408 & 0,20 & Berdistribu \\
$\mathrm{n}$ & 6 & 6 & si normal \\
\hline Kontrol & 0,1848 & 0,20 & Berdistribu \\
& 2 & 6 & si normal \\
\hline
\end{tabular}

Dari tabel analisis uji normalitas pada kelas eksperimen diatas dapat diketahui nilai Lhitung $(0,14086)<$ Ltabel 
$(0,206)$ maka $\mathrm{H}_{0}$ diterima. Sedangkan pada kelas kontrol diketahui L hitung $(0,18482)<$ $\mathrm{L}_{\text {tabel }}(0,206)$ maka $\mathrm{H}_{0}$ diterima.

b. Uji Homogenitas

Tabel 3 Rangkuman Uji Homogenitas

\begin{tabular}{|c|c|c|c|c|}
\hline Kelas & Var & Fhit & Ftabel & Ket \\
\hline Eksperimen & 27,94 & \multirow{2}{*}{1,02} & 2,33 & $\begin{array}{c}\text { Homog } \\
\text { en }\end{array}$ \\
\hline Kontrol & 27,38 & & & \\
\hline
\end{tabular}

Jadi, $F_{\text {hitung }}=1,02<F_{\text {tabel }}=2,33$, maka hipotesis diterima sehingga variansi populasi homogenitas.

Uji hipotesis digunakan dalam nilai hasil tes pada kelas eksperimen dan juga kontrol. Penggunaan Uji t dalam penelitian ini digunakan untuk mengetahui apakah ada perbedaan hasil belajar yang diperoleh dari kelas eksperimen dan juga kelas kontrol. Dari hasil analisis uji hipotesis diperoleh $t_{\text {hitung }}=15,18$ dan $t_{\text {tabel }}$ $=$ 1,684. Karena thitung $>$ tabel maka $\mathrm{H}_{0}$ ditolak dan $\mathrm{H}_{\mathrm{a}}$ diterima. Berdasarkan uji hipotesis yang diperoleh $t_{\text {hitung }}(15,18)>$ $t_{\text {tabel }}(1,694)$ maka dapat diketahui bahwa hasil belajar siswa yang diajar menggunakan model pembelajaran kooperatif dengan Snowball Throwing lebih baik dari pada hasil belajar siswa yang diajar tanpa menggunakan model pembelajaran kooperatif dengan Snowball Throwing.

\section{E. PEMBAHASAN}

Berdasarkan dari hasil analisis data diketahui adanya pengaruh penerapan model pembelajaran kooperatif dengan Snowball Throwing terhadap hasil belajar IPA pada siswa kelas IV SDN Bondrang Kecamatan Sawoo Kabupaten Ponorogo Tahun Pelajaran 2016/2017. Dengan adanya penerapan model pembelajaran kooperatif dengan Snowball Throwing menunjukkan bahwa hasil belajar siswa yang lebih baik dibandingkan dengan penggunaan model pembelajaran yang konvensional.

Penerapan model pembelajaran Snowball Throwing dapat memberikan sebuah jalan keluar untuk mengatasi masalah hasil belajar yang terjadi di SDN Bondrang. Di mana para siswa kurang memiliki semangat untuk mempelajari pembelajaran IPA karena pembelajaran yang lebih ditekankan pada sebuah hafalan yang menyebabkan siswa cepat lupa dan juga sulit untuk memahami materi. Sehingga hal ini mengakibatkan pada hasil belajar IPA yang kurang maksimal.

Sesuai dengan analisis data di atas, dapat diperoleh kesimpulan bahwa pembelajaran dengan menerapkan model pembelajaran Snowball Throwing jauh lebih efektif dibandingkan dengan menggunakan model pembelajaran konvensional. Berdasarkan pada tabel 1 terlihat bahwa hasil belajar siswa kelas eksperimen yang menerapkan model pembelajaran Snowball Throwing memiliki nilai tertinggi 90 dan nilai terendah 75 dengan rata-rata 83,23. Hal ini membuktikan bahwa hasil belajar siswa kelas eksperimen lebih baik dibandingkan dengan kelas kontrol.

Permendikbud Nomor 103 Tahun 2014 menyatakan bahwa : Pembelajaran merupakan suatu proses pengembangan potensi dan pembangunan karakter setiap peserta didi sebagai hasil dari sinergi antara pendidikan yang berlangsung di sekolah, keluarga, dan masyarakat. 
Hamdayana $^{22}$ juga menjelaskan mengenai kelebihan dari model pembelajaran Snowball Throwing bahwa dengan menerapkan model pembelajaran Snowball Throwing dapat membuat suasana menjadi lebih menyenangkan, siswa juga diberikan kesempatan untuk mengembangkan kemampuan berfikir, dan pembelajaran menjadi lebih efektif. Hal ini juga terbukti ketika penelitian berlangsung, dimana siswa menjadi lebih santai dan semangat selama proses belajar berlangsung. Siswa juga menjadi lebih kreatif dan hasil belajar siswa pun menjadi lebih baik.

Berdasarkan tabel 1 menunjukkan adanya perbedaan rata-rata nilai kelas eksperimen yang menerapkan model pembelajaran Snowball Throwing dan kelas kontrol yang tanpa menerapkan model pembelajaran Snowball Throwing. Didalam tabel tersebut ditunjukkan bahwa rata-rata nilai pada kelas eksperimen yang menerapkan model pembelajaran Snowball Throwing mempunyai rata-rata nilai 83,23 , sedangkan pada kelas kontrol yang tidak menerapkan model pembelajaran Snowball Throwing mempunyai rata-rata nilai 71,47.

Jadi dapat disimpulkan dari pembahasan analisis data bahwa penerapan model pembelajaran Snowball Throwing dapat mempengaruhi hasil belajar IPA siswa kelas IV SDN Bondrang dengan perbedaan pada kelas eksperimen nilai tertinggi 90 dan nilai terendah 75 dengan rata-rata nilai 83,23 dan pada kelas kontrol nilai tertinggi 80 dan nilai terendah 65 dengan rata-rata nilai 71,47.

\footnotetext{
${ }^{22}$ Hamdayama, Model Dan Metode Pembelajaran Kreatif Dan Berkarakter, 161.
}

\section{F. KESIMPULAN \& SARAN}

Berdasarkan analisis data dan pembahasan hasil penelitian dapat diambil simpulan bahwa ada pengaruh dari penerapan model pembelajaran kooperatif dengan Snowball Throwing terhadap hasil belajar IPA pada siswa kelas IV SDN Bondrang Kecamatan Sawoo Kabupaten Ponorogo Tahun Pelajaran 2016/2017. Hal ini dibuktikan dengan nilai rata-rata siswa kelas eksperimen adalah 83,23 sedangkan pada kelas kontrol adalah 71,47 .

Sesuai dengan analisis data dan pembahasan hasil penelitian, peneliti menyarankan agar hasil penelitian tersebut dapat membantu meningkatkan hasil pembelajaran IPA di sekolah. Diharapkan hasil penelitian ini dapat ditindak lanjuti oleh pihak yang bersangkutan, yaitu

\section{Bagi Kepala Sekolah}

Kepala sekolah diharapkan mampu untuk mendukung dan juga membantu guru untuk mengembangkan model pembelajaran yang dapat mendukung proses pembelajaran dan yang lebih bervariatif untuk meningkatkan kualitas pendidikan dan SDM yang lebih berkompeten.

\section{Bagi Guru}

Guru diharapkan dapat memilih dan menerapkan model pembelajaran yang akan digunakan dalam proses pembelajaran yang dapat disesuaikan dengan kondisi siswa, materi pembelajaran, serta kondisi kelas yang dapat membantu proses pembelajaran menjadi lebih nyaman dan menyenangkan. 
3. Bagi Peneliti Lain

Sehubungan dengan terbatasnya waktu, tenaga dan juga kondisi, peneliti berharap peneliti lain dapat mempelajari dan memperhatikan penelitian ini dengan seksama agar peneliti lain dapat menindak lanjuti hasil penelitian dengan mengembang-kan penelitian lebih lanjut dengan ruang lingkup penelitian yang lebih luas, sehingga dapat menghasilkan penelitian yang lebih baik untuk meningkatkan kompetensi siswa dan juga dunia pendidikan.

\section{G. DAFTAR PUSTAKA}

Aqib, Z. Model-Model, Media, Dan Strategi Pembelajaran Kontekstual (Inovatif). Bandung: Yrama Widya, 2013.

Baharuddin, and N Esa. Teori Belajar Dan Pembelajaran. Yogyakarta: Ar-Ruzz Media, 2007.

Hamdayama, J. Model Dan Metode Pembelajaran Kreatif Dan

Berkarakter. Bogor: Ghalia Indonesia, 2014.

Huda, M. Model-Model Pengajaran Dan Pembelajaran. Yogyakarta: Pustaka Pelajar, 2013.

Isjoni. Pembelajaran Kooperatif Meningkatkan Kecerdasan Komunikasi Anatar Peserta Didik. Yogyakarta: Pustaka Pelajar, 2011.

Isjoni, and Mohd. Arif. Model-Model Pembelajaran Mutakhir. Yogyakarta: Pustaka Pelajar, 2008.

Malawi, L, and K Anik. Pembaharuan Pembelajaran Di Sekolah Dasar. Magetan: CV. AE Media Grafika, 2015.

Rusman. Belajar Dan Pembelajaran Berbasis Komputer. Bandung: Alfabeta, 2013.
Samatowa, U. Pembelajaran IPA Di Sekolah Dasar. Jakarta Barat: Permata Puri Media, 2010.

Slameto. Belajar Dan Faktor-Faktor Yang Mempengaruhi. Jakarta: Rineka Cipta, 2010.

Sugiyono. Metode Penelitian Kuantitatif, Kualitatif, Dan R\&D. Bandung: Alfabeta, 2013.

Suharto, T. Pengantar Teori Belajar Dan Pembelajaran Bahasa Dan Sastra Berbasis Pengalaman. Salatiga: Widya Sari Press Salatiga, 2015.

Suryani, N, and A Leo. Strategi Belajar Mengajar. Yogyakarta: Penerbit Ombak, 2012.

Susanto, A. Teori Belajar Dan Pembelajaran Di Sekolah Dasar. Jakarta: Kencana Prenadamedia Group, 2013.

Suyono, and Hariyanto. Belajar Dan Pembelajaran Teori Dan Konsep Dasar. Bandung: PT. Remaja Rosdakarya, 2012.

Wisudawati, A.W, and S Eka. Metodologi Pembelajaran IPA. Jakarta: Bumi Aksara, 2014. 
12 | ibriez | Iurnal Kependidikan Dasar $\mid$ Vol 2 No 1 Tahun 2017 